\title{
RECENT DEVELOPMENTS IN INDIANA TORT LAW
}

\author{
PAUL S. KRUSE* \\ LARRY L. MORRIS AND HEATHER D. BOYLE** \\ JANELLE J. RASMUSSEN ${ }^{* * *}$
}

This Article discusses notew orthy case law developments in Indiana tort law during the survey period. It is not intended as a comprehensive or exhaustive overview.

\section{EVIDENCE}

\section{A. Reasonable Value of Medical Bills}

In Patchett v. Lee, ${ }^{1}$ the Indiana Supreme Court held payments made by the Healthy Indiana Plan (HIP) were probative of reasonable value of medical expenses and, thus, admissible under Stanley $v$. Walker. ${ }^{2}$

In this case, Appellee was injured in an automobile accident, sustained numerous injuries, and was billed a total of $\$ 87,706.36$ for treatment of her injuries. ${ }^{3}$ At the time of the accident, Appellee was a member of HIP, a program sponsored by the State of Indiana that provided a more affordable healthcare choice to otherwise uninsured individuals throughout Indiana. ${ }^{4}$ HIP paid Appellee's medical providers a total of $\$ 12,051.48$ in full satisfaction of her medical bills. ${ }^{5}$ Appellee brought a negligence action. ${ }^{6}$ Prior to a trial on damages, she filed a motion in limine seeking to prevent admission of testimony regarding payments made by HIP. ${ }^{7}$ The trial court granted the motion, concluding evidence of the amount HIP paid to reimburse Appellee's medical providers was inadmissible under the collateral source statute ${ }^{8}$ (i.e., the exclusion of accepted

* Partner, Parr Richey Frandsen Patterson \& Kruse LLP since 1984, with practice focusing on a wide range of personal injury matters, including extensive experience handling catastrophic damage and wrongful death claims involving all types of personal injury liability theories. J.D., cum laude, Indiana University Robert H. McKinney School of Law.

** Larry L. Morris is the Administrator for the Court of Appeals of Indiana. J.D., Indiana University Robert H. McKinney School of Law. Heather D. Boyle is the Deputy Senior Law Clerk for Judge Robert R. Altice of the Court of Appeals of Indiana. J.D., Indiana University Robert H. McKinney School of Law.

*** Law Clerk, Parr Richey Frandsen Patterson \& Kruse LLP. J.D., 2016, Northeastern University School of Law.

1. 60 N.E.3d 1025 (Ind. 2016).

2. Id. at 1032-33 (citing Stanley v. Walker, 906 N.E.2d 852 (Ind. 2009)).

3. Id. at $1027-28$.

4. Id. at 1028 .

5. $I d$.

6. $I d$.

7. $I d$.

8. IND. CoDE $\S 34-44-1-2$ (2016). 
reimbursements from government payers) and case law. ${ }^{9}$

The Indiana Supreme Court, relying on Stanley, concluded "[ $t]$ he collateral source statute does not bar evidence of discounted amounts in order to determine the reasonable value of medical services" if insurance is not referenced. ${ }^{10}$ The court then discussed whether evidence of reduced amounts representing "payment in full to a medical provider for services rendered . . . is admissible to prove the reasonable value of those services, consistent with the collateral-source statute."11 The court ultimately held "reduced reimbursements accepted by healthcare providers are relevant, probative evidence of the reasonable value of medical services." 12

The court held Stanley "applies to all accepted reimbursements, regardless of whether they are negotiated or mandated." and Patchett was the identity of the payer ${ }^{14}$ In Stanley, the payer was a private insurance company, whereas in Patchett, the payer was HIP, a government program. ${ }^{15}$ The difference was of no import; the key consideration was that in the end, participating providers accepted "reduced rates in full satisfaction of services rendered." Thus, the court found "such rates are relevant, probative evidence of the reasonable value of medical services." 17

Because no party or friend of the court asked the court to reconsider the holding in Stanley, it adhered to Stanley and took a middle course; it admitted billed charges and accepted amounts, and placed the determination of reasonable value in the hands of the trier of fact. ${ }^{18}$

In Parkview Hospital, Inc. v. Frost ${ }^{19}$ the Court of Appeals of Indiana held when a patient challenges the reasonableness of the amount of hospital charges, the patient is entitled to discovery concerning discounts provided to patients who are covered by government healthcare reimbursement plans. ${ }^{20}$ In Parkview, Appellee was involved in an automobile accident and was treated for his injuries at Appellant's facilities. ${ }^{21}$ Appellee "did not have health insurance at the time he sustained his injuries." ${ }^{22}$ Appellant thus filed a hospital lien in the amount of $\$ 625,117.66$, which included all charges for Appellee's in-patient and skilled
9. $I d$.
10. Id. at 1029 (quoting Stanley v. Walker, 906 N.E.2d 852, 855 (Ind. 2009)).
11. Id.
12. $I d$.
13. Id.
14. Id.
15. Id.
16. Id. at 1031 .
17. Id.
18. Id. at 1032 .
19. 52 N.E.3d 804 (Ind. Ct. App.), trans. denied, 60 N.E.3d 1039 (Ind. 2016).
20. Id. at 810 .
21. Id. at 805 .
22. Id. at 806 . 
nursing care. $^{23}$

Pursuant to the Indiana Hospital Lien Act (the Act), ${ }^{24}$ Appellee filed a declaratory judgment action challenging the "reasonableness of the charges . . . by filing a motion to quash or reduce the claim" in the court where the lien was perfected. ${ }^{25}$ Appellee then served a discovery request on Appellant "requesting information about discounts provided to patients who either had private health insurance or who are covered by government healthcare reimbursement programs. ${ }^{, 26}$ Dissatisfied with Appellant's response, Appellee filed a motion to compel discovery. ${ }^{27}$ Appellant requested a stay of discovery and filed a motion for partial summary judgment "seeking an order that its chargemaster rates were reasonable as a matter of law." ${ }^{, 28}$ Appellee maintained that he was entitled to such information so that he could challenge the reasonableness of the claimed charges. ${ }^{29}$ The trial court agreed that evidence of discounts was relevant to the determination of reasonable charges under the Act. $^{30}$

The court of appeals held because there was a dispute as to whether the chargemaster rates were reasonable, Appellee was entitled to discovery of discounted amounts so that he could challenge Appellant's prima facie evidence of reasonableness with contradictory evidence. ${ }^{31}$

In dissent, Judge Najam opined that the supreme court's decision in Allen v. Clarian Health Partners, Inc., ${ }^{32}$ was controlling precedent to the extent it held the contract term requiring patients to pay "the account" was a reference to the hospital's chargemaster rates. ${ }^{33}$ In Allen, the supreme court refused to impute a "reasonable" price term into the contract. ${ }^{34}$

\section{B. Risk of Harm Issues}

In Green v. Robertson, ${ }^{35}$ the court of appeals held "if recovery is limited to damages for increased risk of harm, the [Patient's Compensation Fund (PCF)] is entitled to introduce evidence of the patient's underlying risk of harm to assist the factfinder in determining the appropriate amount of damages. ${ }^{\prime 36}$

23. $I d$.

24. See InD. CODE $\S 32-33-4-1$ to -8 (2016).

25. Id. at 806 (quoting IND. CoDE $\S 32-33-4-4(\mathrm{e})$ (2016)).

26. $I d$.

27. $I d$.

28. Id.

29. Id. at 807 .

30. Id. at 806 .

31. Id. at 810 .

32. 980 N.E.2d 306 (Ind. 2012).

33. Parkview Hosp., Inc., 52 N.E.3d at 810 (Najam, J., dissenting).

34. Id. (citing Allen, 980 N.E.2d at 311).

35. 56 N.E.3d 682 (Ind. Ct. App. 2016), trans. denied, 2017 Ind. LEXIS 99 (Ind. Feb. 9, 2017).

36. Id. at 693 . 
Plaintiff was taken to an emergency room after suffering nausea, weakness, numbness, and "loss of motor function on the left side of his body, drooping on the left side of his face, headache, and difficulty speaking." ${ }^{37}$ Plaintiff was diagnosed with nausea and vomiting and released from the hospital. ${ }^{38}$ When later taken to a second hospital, it was determined that Plaintiff had suffered a stroke. ${ }^{39}$ Evidence presented during the bench trial showed that if patients who are suffering strokes are treated with a clot-busting drug within three hours of onset of the stroke, such treatment may minimize the effects; however, Plaintiff would have suffered from fatigue, stamina issues, and some level of physical deficits even with successful treatment. ${ }^{40}$

Plaintiff filed a proposed complaint with the Indiana Department of Insurance and eventually reached a settlement agreement with the named defendants, whereby the parties agreed to a structured settlement totaling $\$ 250,000 .{ }^{41}$ Plaintiff then filed a petition for excess damages from the PCF alleging that he experienced post-stroke injuries that were caused by the failure of doctors and staff at the first hospital to adequately assess, evaluate, and treat his neurological condition. ${ }^{42}$ The trial court awarded Plaintiff $\$ 300,000$ in excess damages from the PCF "for the aggravation of his condition, the injury associated with the corneal scarring, pain and suffering, and loss of enjoyment of life." ${ }^{43}$ However, the court determined Plaintiff should receive only thirty-nine percent of the total cost associated with his injury "because this was the chance of recovery if [the Plaintiff] had properly been treated." ${ }^{\prime 4}$ Plaintiff appealed, arguing that the trial court erred in awarding him only $\$ 300,000$ in additional compensation. ${ }^{45}$

The court of appeals addressed the issue of increased risk of harm as set forth in the Restatement (Second) of Torts $\S 323$ (1965), noting "even if a claim was settled, if recovery is limited to damages for increased risk of harm, the PCF is entitled to introduce evidence of the patient's underlying risk of harm to assist the factfinder in determining the appropriate amount of damages." ${ }^{46}$ Our supreme court has held "damages for such a claim are to be measured in proportion to the increased risk, and not by the full extent of the ultimate injury." 47

In light of its findings regarding the effectiveness of the drug, the trial court reduced Plaintiff's damage award proportionally. ${ }^{48}$ The trial court considered evidence of the varying degrees of effectiveness of the clot-busting drug, noting

37. Id. at 684 .

38. Id.

39. Id. at 685 .

40. Id. at 686,688 .

41. Id. at 685 .

42. Id. at 685-86.

43. Id. at 694 .

44. Id. at 695-96.

45. Id. at 696 .

46. Id. at 692-93.

47. Cahoon v. Cummings, 734 N.E.2d 535, 538 (Ind. 2000).

48. Id. at 695-96. 
that one study showed "only $39 \%$ of patients who receive tPA within three hours of a stroke have minimal or no disability three months later." ${ }^{49}$ An expert opined that Plaintiff had a $12.5 \%$ chance of having minimal or no disability if timely treated. ${ }^{50}$ The court of appeals concluded the trial court's decision to reduce Plaintiff's award by sixty-one percent (as opposed to $8.5 \%$ ) to be within the scope of the evidence. ${ }^{51}$ The court of appeals affirmed the trial court's judgment aw arding Plaintiff $\$ 300,000$ from the PCF. ${ }^{52}$

\section{Intervening Cause/Injury}

In State Farm Mutual Automobile Insurance Co. v. Woodgett, ${ }^{53}$ the Indiana Court of Appeals held evidence of a second collision could not be excluded because it was a possible cause of the plaintiff's injuries. ${ }^{54}$

During the afternoon of September 20, 2011, motorist Woodgett was rearended, causing his vehicle to roll into the back of another vehicle. ${ }^{55}$ Woodgett was treated for neck pain and a headache on the day of the accident and for "intermittent stress headaches" and neck pain about a month later. ${ }^{56}$ After undergoing five physical therapy sessions, Woodgett reported that he had slight headaches that came infrequently, and that he was able to engage in recreational activities with no neck pain. ${ }^{57}$ In the fall of 2012 , Woodgett was involved in a second crash, which he described as a minor sideswipe crash that caused no injuries. ${ }^{58}$

In January 2013, Woodgett saw a neurologist for what he described as two types of headaches he was experiencing, including a daily mild headache and a severe headache three-to-four times a week that could be "unbearable." 59 Woodgett noted that since the September 2011 accident, his mild headaches "gradually got worse." 60

On February 25, 2013, Woodgett filed a complaint for damages against the driver of the vehicle that ran into him on September 20 and against State Farm, pursuant to his uninsured motorist coverage. ${ }^{61}$

At the outset of the jury trial, Woodgett's counsel sought a motion in limine to prohibit the defense from discussing the 2012 accident as an intervening

49. Id. at 696-97.

50. Id. at 697 .

51. Id.

52. Id.

53. 59 N.E.3d 1090 (Ind. Ct. App. 2016).

54. Id. at 1097.

55. Id. at 1091.

56. Id. at 1091-92.

57. Id. at 1092 .

58. Id.

59. Id.

60. Id.

61. Id. 
cause. ${ }^{62}$ Counsel noted that although Woodgett affirmatively answered that his headaches progressively got worse after the 2012 crash, he also explained that the 2012 crash did not cause them to get worse; his headaches had been getting worse for a period of time before that crash, and they kept getting worse thereafter. ${ }^{63}$

State Farm, directing the trial court's attention to the standard set forth in Walker v. Cuppett, maintained that given the timing of events in relation to Woodgett's complained-of injury, the jury would not have to speculate regarding the effect of the second accident. ${ }^{64}$ The trial court ultimately granted Woodgett's motion upon its determination that because there was no medical evidence that directly addressed the issue of the injury Woodgett suffered as a result of the second accident, the jury would have been left to speculate as to the injury that the second collision caused. ${ }^{65}$

State Farm appealed and the court of appeals identified the dispositive issue as whether the trial court abused its discretion in excluding the evidence of the second accident. ${ }^{66}$ In reviewing the trial court's analysis, the court of appeals noted that $D a u b$ addressed a plaintiff's burden of proving causation and did not address "the relevancy standard applicable to the admission of evidence a defendant wishes to present in a personal injury action. ${ }^{" 67}$ The court then noted that the appropriate standard, followed in Walker, was that the admissibility of evidence to show the injury complained of is due to some other cause where the present injury and the prior injury are similar and where there is a "logical nexus" is "not probability, but the possibility that a plaintiff's claimed damages resulted from a condition or event unrelated to the defendant's negligence." 68

Applying this standard, the court of appeals noted deposition testimony from the neurologist to the effect that post-traumatic migraine headaches could result from "pretty minor trauma," and it was not until after the second accident that Woodgett sought treatment for daily mild headaches and debilitating headaches several times a week. ${ }^{69}$ The court of appeals held the trial court abused its discretion in excluding evidence of the second accident because under the facts "a logical nexus exists between the second accident and the migraine headaches sufficient such that the second accident was a possible cause of such headaches." ${ }^{70}$

62. Id.

63. Id.

64. Id. at 1092-93 (citing Walker v. Cuppett, 808 N.E.2d 85 (Ind. Ct. App. 2004)).

65. Id. at 1093. The trial court's decision was based in part on Daub v. Daub, 629 N.E. $2 \mathrm{~d} 873$

(Ind. Ct. App. 1994).

66. Id.

67. Id. at 1097 (citing Daub, 629 N.E.2d 873).

68. Id. at 1096 (quoting Walker, 808 N.E.2d at 95-96)).

69. Id. at 1097.

70. Id. 


\section{PROCEDURE}

\section{A. Summary Judgment}

In Siner v. Kindred Hospital Ltd. Partnership d/b/a Kindred Hospital of Indianapolis ${ }^{71}$ the Indiana Supreme Court held where defendants' designated evidence revealed conflicting medical opinions on the element of causation, summary judgment was inappropriate. ${ }^{72}$

Siner was admitted to the hospital for treatment. ${ }^{73}$ A dispute regarding her code status arose, so the family arranged for transport to another hospital that would respect their wishes. ${ }^{74}$ Siner was transferred to a different hospital, where she required immediate treatment for a collapsed lung. ${ }^{75}$ It was also determined that she was suffering from wounds on her cheeks, overwhelming infection, and septic shock. ${ }^{76}$ Siner died twenty days later. ${ }^{77}$ Siner's family filed a medical malpractice complaint with the Department of Insurance against the first hospital and those who treated Siner (Defendants). ${ }^{78}$ The medical review panel issued a unanimous opinion "that the evidence supports the conclusion that the defendants failed to comply with the appropriate standard of care, and that their conduct may have been a factor of some resultant damages, but not the death of the patient."79

Siner's family filed a complaint with the trial court alleging malpractice "on multiple acts or occurrences," resulting in "multiple injuries to [Siner's] nervous system, respiratory system, cardiovascular system, [and] musculoskeletal system. $"{ }^{80}$ Defendants moved for summary judgment and designated the review panel's decision in addition to an affidavit from a member of the review panel stating that Defendants did not cause injury to Siner in administering her pulmonary care. ${ }^{81}$

The court first noted summary judgment determinations are made from the evidence designated to the court. ${ }^{82}$ The evidence designated by Defendants related only to Plaintiffs' pulmonary claims and did not relate to the non-pulmonary claims. ${ }^{83}$ The court therefore held summary judgment on the non-pulmonary claims was inappropriate. ${ }^{84}$

71. 51 N.E.3d 1184 (Ind. 2016).

72. Id. at 1190.

73. Id. at 1186.

74. Id.

75. Id.

76. Id.

77. Id.

78. $I d$.

79. Id. (emphasis added).

80. Id. at 1188 .

81. Id.

82. Id.

83. Id. at 1189.

84. Id. 
The court also noted that although the medical review panel's opinion contained no specific facts, the medical conclusions contained therein conflicted with other designated affidavits as to the ultimate issue of causation. ${ }^{85}$ Specifically, the court referred to expert affidavits indicating that Defendants' conduct did not injure Siner, which was in conflict with the medical review panel's conclusion that "their conduct may have been a factor of some resultant damages." ${ }^{\prime 6}$ Emphasizing summary judgment is inappropriate whenever "a conflict of evidence may exist" on a material issue, the court held summary judgment was inappropriate. ${ }^{87}$

In Hill v. Gephart, ${ }^{88}$ the court of appeals held whether a pedestrian who violated a statute imposing a duty thereon acted reasonably or was contributorily negligent was a matter for resolution by the trier of fact. ${ }^{89}$

Hill and his daughter walked to a nearby park along a roadway between their home and the park, which were on the same side of the street. ${ }^{90}$ Near dusk, Hill and his daughter decided to walk home along the same roadway, with Hill's daughter walking in front of him. ${ }^{91}$ They did not cross the street in order to walk against traffic, but rather walked along the right side of the roadway with their backs toward traffic. ${ }^{92}$ Hill claimed that he believed this was safer than having to cross the street twice in order to get home. ${ }^{93}$ Hill was using his phone as he walked along the roadside when he was struck by a jail transport vehicle driven by Deputy Gephart. ${ }^{94}$ An accident reconstruction specialist could not determine Hill's exact location at the time of impact and ultimately concluded that the primary cause of the accident was the low-light environment and the dark clothes Hill wore at the time. ${ }^{95}$ The Hills filed a complaint alleging negligence and negligent infliction of emotional distress. ${ }^{96}$ The trial court "dismissed the Hills' complaint against Deputy Gephart and granted summary judgment in favor of the remaining Defendants." ${ }^{97}$

The Hills argued that Defendants' defense of contributory negligence on behalf of Hill was an issue to be decided by the trier of fact. ${ }^{98}$ Hill conceded he violated Indiana Code section 9-21-17-14 when he walked on the right side of the

85. Id.

86. Id. at 1186 (emphasis added).

87. Id. at 1190 .

88. 54 N.E.3d 402 (Ind. Ct. App. 2016), aff'd on reh'g, 62 N.E.3d 408, trans. denied, 64 N.E.3d 1205 (Ind. 2016).

89. Id. at 407.

90. Id. at 404 .

91. Id.

92. Id.

93. Id. at 407 .

94. Id. at 404 .

95. Id. at 405 .

96. $I d$.

97. Id.

98. Id. at 406 . 
roadway, but asserted that such a violation only creates a rebuttable presumption of negligence. ${ }^{99}$ In such cases, the person who disobeyed a statute "may excuse or justify the violation in a civil action for negligence by sustaining the burden of showing that he did what might be reasonably expected by a person of ordinary prudence, acting under similar circumstances, who desired to comply with the law." ${ }^{100}$ Although this rule was announced in considering the duty of a driver who violated a motor vehicle statute, the court concluded that it should be extended to motor vehicle statutes that impose duties on pedestrians. ${ }^{101}$ Hill claimed his violation of the statute was justifiably reasonable and was arguably the safer option for him and his daughter because they did not have to cross the street. ${ }^{102}$ The court held Hill's assertion in this regard created a genuine issue of material fact as to whether Hill's conduct was reasonable or if he contributed to his injuries. ${ }^{103}$ Thus, summary judgment was inappropriate. ${ }^{104}$

In Sorrells v. Reid-Renner, ${ }^{105}$ the court of appeals held summary judgment was precluded because there was a genuine issue of material fact as to whether a physician's alleged negligence was the proximate cause of injuries and damages to the patient. ${ }^{106}$

Appellant filed a malpractice complaint against her physician, alleging that her physician failed to communicate the results of a blood test that were indicative of her early-stage leukemia. ${ }^{107}$ Appellant claimed that this resulted in a delay in diagnosis, which, in turn, caused her injury and damages. ${ }^{108}$ Appellant's oncologist stated that if Appellant had been timely informed and properly monitored, he would have had "a much better idea of what her disease process was" and explained how the treatment plan may have been different, such that he may have not treated Appellant with chemotherapy, and Appellant may have not needed a port. ${ }^{109}$ A medical review panel concluded the physician breached the standard of care, but opined that such was not a causative factor in any resultant injury or damages. ${ }^{110}$

Although the medical review panel found in favor of the physician on the issue of causation, expert testimony, when considered in the light most favorable to Appellant, created a genuine issue of fact on the issue of proximate cause, thereby precluding summary judgment. ${ }^{111}$

99. Id. at 406-07; see Davison v. Williams, 242 N.E.2d 101, 105 (Ind. 1968).

100. Id. at 407 (quoting Davison, 242 N.E.2d at 105).

101. Id.

102. Id.

103. Id.

104. Id.

105. 49 N.E.3d 647 (Ind. Ct. App. 2016).

106. Id. at 652 .

107. Id. at 649 .

108. Id.

109. Id.

110. Id. at 648 .

111. Id. at 652 . 
The court of appeals also rejected the physician's "implication that the only significant inquiry [was] whether the delay in diagnosis affected [Appellant's] ultimate prognosis or life expectancy." 112 There was no dispute that it did not. ${ }^{113}$ The court held "merely because the delayed diagnosis did not exacerbate [Appellant]'s disease, that is not to say that it was not the proximate cause of some injury or damages to her" as a result of additional aggressive and expensive medical treatments and procedures that would have been unnecessary had the physician complied with the applicable standard of care. ${ }^{114}$

In Scripture v. Roberts, ${ }^{115}$ the court of appeals held in order to defeat summary judgment, a physician's affidavit must include at least some facts that would support a finding that the physician met the standard of care or that the physician's conduct did not cause injury or damage to the patient. ${ }^{116}$ The court of appeals also determined where a party timely filed summary judgment affidavits, albeit inadequate ones, the trial court did not abuse its discretion in refusing to permit the party to cure the deficiency by filing supplement affidavits months later and on the eve of the summary judgment hearing. ${ }^{117}$

Appellee suffered an injury to her left eye that required a corneal transplant. ${ }^{118}$ The injury resulted from the care and treatment of several physicians. ${ }^{119}$ A unanimous medical review panel found the physicians "failed to comply with the appropriate standard of care" and their conduct was a causal factor in the damages suffered by Appellee. ${ }^{120}$ Appellee filed a complaint and then moved for summary judgment, designating as evidence the opinion of the medical review panel. ${ }^{121}$ In response to Appellee's motion for summary judgment, the physicians designated as expert evidence their own affidavits. ${ }^{122}$ Months later and one day prior to the summary judgment hearing, the physicians sought to supplement their response to summary judgment with their own supplemental affidavits that included facts to support their conclusions. ${ }^{123}$ The trial court denied their request to supplement and granted summary judgment in favor of Appellee. ${ }^{124}$

In reviewing the grant of summary judgment, the court of appeals addressed "whether the particular facts alleged in the [physicians'] affidavits were specific

112. Id.

113. $I d$.

114. $I d$.

115. 51 N.E.3d 248 (Ind. Ct. App. 2016).

116. Id. at 249 .

117. Id. at 255 .

118. Id. at 249 .

119. Id.

120. Id.

121. Id. at 250 .

122. Id.

123. Id.

124. Id. 
enough to raise a genuine issue of material fact." ${ }^{125}$ In their respective affidavits, the physicians set out their medical credentials, stated the dates on which they provided care to Appellee, indicated that they were each familiar with the treatment provided by the others, acknowledged the appropriate standard of care, and stated a general conclusion that the treatment they individually provided met the applicable standard of care. ${ }^{126}$

To defeat summary judgment, an expert's affidavits must include at least some factual basis to support the expert's conclusion. ${ }^{127}$ The physicians argued that even if their affidavits were self-serving and conclusory, under the standard enunciated by the Indiana Supreme Court in Hughley v. State, their affidavits were sufficient to defeat summary judgment. ${ }^{128}$ The court of appeals found Hughley inapposite, noting the physicians cited no facts that would support a finding that they met the standard of care or that their conduct did not cause Appellee's damages; rather, the physicians "merely restated the denials in their pleadings." ${ }^{29}$ The court held the physicians' affidavits failed to create a genuine issue of material fact. ${ }^{130}$

The court of appeals also determined the trial court did not abuse its discretion in denying the physicians' request to supplement their respective affidavits where the physicians timely filed their initial, factually inadequate affidavits, but waited months - until the day before the summary judgment hearing - "to step up their efforts to defeat summary judgment" by filing affidavits that contained additional information that cured the alleged deficiencies. ${ }^{131}$

In City of Beech Grove v. Beloat,${ }^{132}$ the Indiana Supreme Court held the city did not meet its burden on summary judgment to prove it was entitled to discretionary-function immunity for a suit a pedestrian, Beloat, filed after she stepped in a hole in the pavement. ${ }^{133}$

As Beloat crossed a street in Beech Grove, her foot went into a hole in the pavement and she tripped and broke her leg. ${ }^{134}$ The City moved for summary judgment, claiming discretionary-function immunity under Indiana Code section 34-13-3-3(7) (2014), and its motion was denied. ${ }^{135}$ The court of appeals reversed and directed entry of summary judgment for the City. ${ }^{136}$ The supreme court

125. Id. at 251 .

126. Id. at 252 .

127. Id. at 253 .

128. Id. at 254 (citing Hughley v. State, 15 N.E.3d 1000 (Ind. 2014)).

129. Id.

130. Id.

131. Id. at 255 .

132. 50 N.E.3d 135 (Ind. 2016).

133. Id. at 143 .

134. Id. at 137.

135. Id.

136. Id. 
granted transfer. ${ }^{137}$

Like the court of appeals, the supreme court looked to Peavler v. Board of Commissioners, wherein the court adopted the "planning/operational test" for addressing claims of discretionary-function immunity. ${ }^{138}$ The court reiterated that the test serves to "insulate[] only those significant policy and political decisions which cannot be assessed by customary tort standards. The assessment requires close consideration of the nature of the governmental actions and the decisionmaking process that was involved." 139 Merely labeling an activity or omission "as planning or operational, without more, is insufficient to determine whether immunity exists." 140

The City designated as evidence the mayor's affidavit and minutes from meetings of the city council and the Board of Works and Safety. ${ }^{141}$ The supreme court noted prior cases that have reiterated " $[t]$ he actions of individual members of a board or commission outside a meeting cannot be substituted for the actions at a duly constituted meeting or for the minutes thereof." ${ }^{142}$ Thus, the court discounted the mayor's affidavit insofar as it was relied upon to demonstrate that the City engaged in a policy determination in this case because the mayor's comments and actions were not actions of the board. ${ }^{143}$ The court determined the balance of the designated evidence was also lacking as to the nature of the decision-making process and the project itself. ${ }^{144}$ The court therefore concluded there was insufficient designated evidence to establish that the City was entitled to assert discretionary-function immunity. ${ }^{145}$

\section{A. Statute of Repose}

In Myers v. Crouse-Hinds Division of Cooper Industries, Inc., ${ }^{146}$ the Indiana Supreme Court declined to reconsider its decision in Allied Signal v. Ott, ${ }^{147}$ but held Indiana Code section 34-20-3-2 (2014) violates article 1, section 23 of the equal privileges and immunities clause of the Indiana Constitution. ${ }^{148}$ As held in Covalt v. Carey Canada, Inc., ${ }^{149}$ the Indiana Product Liability Act's statute of repose $^{150}$ does not apply to cases involving protracted exposure to an inherently

137. Id.

138. Id. at 138 (citing Peavler v. Bd. of Comm'rs, 528 N.E.2d 40, 45-46 (Ind. 1988)).

139. Id.

140. Id.

141. Id. at 140 .

142. Id.

143. $I d$.

144. $I d$.

145. Id.

146. 53 N.E.3d 1160 (Ind.), reh'g denied, 53 N.E.3d 1173 (Ind. 2016).

147. 785 N.E.2d 1068 (Ind. 2003).

148. Myers, 53 N.E.3d at 1162, 1167.

149. 543 N.E.2d 382 (Ind. 1989).

150. See InD. CoDE $\S 34-20-3-1,-2$ (2016). 
dangerous foreign substance that is visited into the body, such as asbestos. ${ }^{151}$

Appellants filed complaints alleging damages stemming from asbestos-caused diseases that developed years after exposure to asbestos. ${ }^{152}$ The supreme court consolidated three appeals that presented the same principal issues relating to application of Indiana's Product Liability Act's ten-year statute of repose. ${ }^{153}$ Appellants first urged the court to reconsider its holding in Ott and adopt the interpretation presented by the $O t t$ dissent. ${ }^{154}$ The court declined this request, but did address Appellants' constitutional arguments that the statute of repose violated two provisions of the Indiana Constitution: the right to remedy clause, article 1, section 12, and the equal privileges and immunities clause, article 1, section $23 .{ }^{155}$

In $O t t$, the majority considered the applicability of Indiana Code section 3420-3-1, which generally applies to product liability claims (section 1), and Indiana Code section 34-20-3-2, which specifically applies to at least some asbestos liability claims (section 2). ${ }^{156}$ The court noted that although product liability actions under section 1 have a two-year statute of limitations and a tenyear statute of repose, asbestos-related actions under section 2 enjoy a different timetable. ${ }^{157}$ When a product liability action qualifies under section 2 , there is no firm statute of repose. ${ }^{158}$ Rather, a lawsuit must be commenced within two years "after the cause of action accrues," with the accrual date defined as "the date when the injured person knows that the person has an asbestos related disease or injury." 159 The Ott majority held only those persons who produce asbestos (i.e., "mine[] and s[ell] commercial asbestos") fall within section 2; all others who sell asbestos-containing products fall within the ambit of section $1 .{ }^{160}$

In the present case, Appellants brought a different article 1, section 23 claim than was presented in $O t t$, defining the different classes as asbestos victims injured by defendants who both mined and sold raw asbestos compared to asbestos victims injured by other defendants. ${ }^{161}$ The court noted that both classes were "identically comprised of asbestos victims." 162 Applying the standard set forth in Collins v Day, the court concluded section 2, by not differentiating between the classes based on any single characteristic of theirs-inherent or otherwise-created disparate treatment in that some asbestos victims fell within section 1, where their claims may be barred by the statute of repose, and other

151. Myers, 53 N.E.3d at 1167 (citing Covalt, 543 N.E.2d at 385).

152. Id.

153. Id. at 1162 .

154. Id. (citing Allied Signal v. Ott, 785 N.E.2d 1068 (Ind. 2003)).

155. Id. at 1164 .

156. Id. at 1165 .

157. Id.

158. Id.

159. Id. at 1163 n.4 (quoting IND. CODE $§ 34-20-3-2$ (a) and (b) (2016)).

160. Id. at 1163 .

161. Id. at 1164 .

162. Id. at 1165 . 
asbestos victims fell within section 2 , where no statute of repose applies. ${ }^{163}$ The court further concluded although the two classes of asbestos victims are similarly situated, only one of them is completely exempted from the statute of repose. ${ }^{164}$ The court held the unequal treatment of asbestos victims under section 2 of the Indiana Product Liability Act violates article 1, section 23; therefore, the court invalidated section $2 .{ }^{165}$

The court then turned to the application of section 1, looked to the analysis of the Ott majority, and the interpretation by the court in Covalt. ${ }^{166}$ Because Covalt interpreted section 1 standing alone, and that section does indeed now stand alone following this decision, the court restored Covalt's precedential value as to its holding that "our statute of repose [is] inapplicable to cases involving protracted exposure to an inherently dangerous foreign substance which is visited into the body." 167

\section{AGENCY}

\section{A. Respondeat Superior}

In Knighten v. East Chicago Housing Authority, ${ }^{168}$ the Indiana Supreme Court reiterated that the scope of an employee's duties and responsibilities, and whether the employee's "act was done 'to an appreciable extent, to further his employer's business," presents a question of fact to be determined by the factfinder. ${ }^{169}$

The East Chicago Housing Authority operated a federal housing complex in East Chicago, and contracted with Davis Security Services, LLC to provide security services for said complex in 2009-2011. ${ }^{170}$ In 2008, Davis Security hired Donnell Caldwell as a security guard. ${ }^{171}$ In mid-2010, Caldwell was assigned to work in the guard shack and monitor traffic coming into the housing complex. ${ }^{172}$ Stacy Knighten, with whom Caldwell had once been romantically involved and who lived in the housing complex, encountered Caldwell while he was working security; the two became involved in a heated argument during which they ventured several yards away from Caldwell's post in the guard shack. ${ }^{173}$ After damaging the entrance gate to the complex, and some time later, Knighten began walking away from Caldwell, but "Caldwell drew his handgun and fired a shot striking Knighten in the back"; this "gunshot injury left Knighten paralyzed from

163. Id. (citing Collins v Day, 644 N.E.2d 72, 80 (Ind. 1994)).

164. Id. at 1166 .

165. Id. at 1168 .

166. Id.

167. Id. at 1167 (quoting Covalt v. Carey Canada, Inc., 543 N.E.2d 382, 385 (Ind. 1989)).

168. 45 N.E.3d 788 (Ind. 2015).

169. Id. at 794 .

170. Id. at 790 .

171. Id.

172. Id.

173. Id. 
the waist down." 174

Knighten filed a complaint for damages against the Housing Authority, Davis Security, and Caldwell and further alleged liability on behalf of the Housing Authority and Davis Security for negligent hiring and supervision. ${ }^{175}$ Summary judgment was granted in favor of the Housing Authority and Davis Security on all claims; Knighten appealed only the grant of summary judgment in favor of Davis Security. ${ }^{176}$

Knighten's claim against Davis Security was premised upon the doctrine of respondeat superior, under which an employer can be held liable "for the wrongful acts of [its] employee which are committed within the scope of employment." "[I7] "[I]n order for an employee's act to fall 'within the scope of employment,' the injurious act must be incidental to the conduct authorized or it must, to an appreciable extent, further the employer's business." ${ }^{" 178}$ If the employee's conduct occurs within an independent course of conduct not intended by the employee to serve any purpose of the employer, then the employee's conduct is not within the scope of employment. ${ }^{179}$

Davis Security asserted that Caldwell's sole duty was to monitor traffic. ${ }^{180}$ The court noted "tension - if not outright conflict" between this assertion and the fact that Caldwell was also armed with a gun, indicating potentially more duties. ${ }^{181}$ The court also noted conflicting evidence that the Housing Authority's contract with Davis Security required Davis Security to have an armed employee at the guard shack, while Schmidt's supervisor testified by way of deposition that Schmidt was instructed that he should not be armed. ${ }^{182}$ The court stated:

If, as Davis Security alleges, it prohibited Caldwell from possessing a handgun while serving as a security guard then that fact would certainly undermine the notion that he used his handgun in furtherance of his employer's business. On the other hand if Caldwell [was] required to be armed on duty, then the use of his firearm could very well have been necessary. ${ }^{183}$

The court also considered evidence regarding Caldwell's location at the time of the shooting, i.e., away from the guard shack, and noted that resolution of the disputed facts may also tip the scales in favor of one party or the other. ${ }^{184}$ Based on the foregoing considerations, the court held:

174. Id.

175. Id.

176. Id. at 791.

177. Id.

178. Id. at 792 .

179. Id.

180. Id.

181. Id.

182. Id. at 793 .

183. Id.

184. Id. at 793-94. 
In the end, the scope and extent of Caldwell's duties and responsibilities as an employee of Davis Security, and whether in discharging his weapon Caldwell engaged in conduct consistent with his duties and responsibilities, and thus whether this act was done "to an appreciable extent, to further his employer's business[,]" are matters that cannot be resolved by summary disposition. ${ }^{185}$

In Robbins v. Trustees of Indiana University, ${ }^{186}$ the court of appeals held an employer was not vicariously liable under the respondeat superior doctrine where the employee nurse acted for personal purposes, and the negligent hiring claim failed where the harm to the patient was not reasonably foreseeable. ${ }^{187}$

In her application for a job with the Indiana University School of Medicine, DeBow noted her employment history, as well as a prior conviction for misdemeanor battery. ${ }^{188}$ DeBow also read and signed a Commitment to Confidentiality Agreement as part of the application process, wherein she agreed to keep medical records confidential and not to disclose them for "personal, unauthorized, unethical, or illegal reason [s]." ${ }^{, 189}$ Following additional independent screening measures, DeBow was offered a position providing health care services and provided with credentials to access two electronic medical records systems. ${ }^{190}$ DeBow accessed Robbins's medical records and those of Robbins's children for no legitimate business reason and posted the information on an Internet blog. ${ }^{191}$ When confronted, DeBow admitted she had posted confidential information and that her motive was revenge. ${ }^{192}$ DeBow pled guilty to a federal felony charge related to the disclosure of confidential information. ${ }^{193}$

Robbins filed a complaint alleging that the defendants were vicariously liable for DeBow's actions, "who allegedly committed the torts of invasion of privacy by the public disclosure of private facts and intentional infliction of emotional distress," or, alternatively, that the defendants were liable for negligently hiring DeBow. ${ }^{194}$ The trial court granted the defendants' motion for summary judgment. ${ }^{195}$

The court of appeals held where the agreement setting forth the relationship between the defendants did not give the defendants "an equal right to direct and govern any undertaking and [did] not provide for the sharing of profits," the defendants were "not in a joint venture for the purpose of a finding of vicarious

185. Id. at 794 (internal citations omitted).

186. 45 N.E.3d 1 (Ind. Ct. App. 2015).

187. Id. at 7,12 .

188. Id. at 4 .

189. Id.

190. Id. at 4-5.

191. Id. at 5.

192. Id.

193. Id.

194. Id.

195. Id. 
liability." 196 The court also noted that simply issuing a username and password to access the records system did not give rise to an agency relationship between defendants and DeBow. ${ }^{197}$

Although DeBow accessed Robbins's medical records while at work, DeBow's admission that she did so for personal reasons and not in conjunction with her employment, her admission that she was motivated by revenge, and the fact that she had read and signed a confidentiality agreement weighed in favor of the conclusion that her actions were not sufficiently associated with her employment duties to fall within the scope of her employment. ${ }^{198}$ Summary judgment was therefore properly granted..$^{199}$

The court also rejected Robbins's negligent-hiring claim. ${ }^{200}$ The designated evidence established that DeBow's employment did not put her in contact with Robbins, DeBow was not authorized to access Robbins's electronic medical records when Robbins was not a patient of the department where DeBow worked, DeBow's conduct was not a recurring event, and there were no prior reports that DeBow had engaged in similar conduct. ${ }^{201}$ Based on this evidence, the court concluded Robbins was not a reasonably foreseeable victim. ${ }^{202}$

\section{B. Duty of Physician Overseeing a CPA}

In Collip v. Ratts, ${ }^{203}$ the court of appeals held licensed physicians who undertake the responsibility to oversee the prescribing practices of nurse practitioners owe a duty to the nurse practitioners' patients to fulfill their contractual obligations with reasonable care, and the physician's duty existed even though the physician had never treated the patient. ${ }^{204}$

"Under Indiana law, a nurse practitioner cannot prescribe legend drugs without a collaborative practice agreement [(CPA)] with a licensed physician." 205 Here, Physician entered into such an agreement with Nurse Practitioner, wherein Physician was to collaborate with and oversee Nurse Practitioner's prescriptive practices. ${ }^{206}$ Physician admitted that he never complied with the term of the CPA requiring him to review at least five percent of the charts of Nurse Practitioner's patient, but that he had become concerned about the amount of narcotics she was prescribing. ${ }^{207}$ One of Nurse Practitioner's patients died as a result of mixed drug

196. Id. at 7 .

197. Id.

198. Id. at 10.

199. Id. at 11 .

200. Id. at 12 .

201. $I d$.

202. Id.

203. 49 N.E.3d 607 (Ind. Ct. App. 2015).

204. Id. at 610 .

205. Id.

206. $I d$.

207. Id. 
interaction. ${ }^{208}$ The mother of the deceased filed a complaint against Physician, Nurse Practitioner, and Nurse Practitioner's practice. ${ }^{209}$ Cross-motions for partial summary judgment between decedent's mother and Physician were considered by the trial court. ${ }^{210}$ The trial court entered partial summary judgment in favor of decedent's mother. ${ }^{211}$

On interlocutory appeal, the court of appeals determined the case should be considered under general tort principles, and looked to Webb v. Jarvis in considering whether the physician "had a legal duty to a third party to whom he had not provided any medical treatment." ${ }^{212}$ The court noted that Physician voluntarily entered into a contract with Nurse Practitioner to provide oversight of prescriptive services and the "gravamen of such a contract is the protection of the nurse practitioner's patients." 213 Thus, despite the lack of privity between the parties, the court held this evidence weighed in favor of finding the existence of a duty. ${ }^{214}$

With regard to the foreseeability of harm, the court noted the statutory requirement that "nurse practitioners may prescribe legend drugs only when under the supervision of a physician" and the clear implication was that this requirement was enacted to "ensure the safety of the patients of nurse practitioners." 215 The court thus held it was "eminently foreseeable" that a physician's failure to perform his or her oversight duties could result in a nurse practitioner's patient being harmed. ${ }^{216}$ The court also held a multitude of public policy reasons weigh in favor of imposing a duty on the overseeing physician. ${ }^{217}$ In so holding, the court noted that a contrary conclusion would permit physicians to "put their proverbial blinders on," and would provide them with no incentive to oversee a nurse practitioner's work in a responsible manner. ${ }^{218}$

The court also addressed Physician's argument that he owed no duty to Nurse Practitioner's patient pursuant to section 324A of the Restatement (Second) of Torts. ${ }^{219}$ The court rejected this argument, noting that because Physician voluntarily entered the CPA, expressly agreed to direct and oversee Nurse Practitioner in her practice, and was paid for his services, section 324A did not shield Physician from owing a duty to Nurse Practitioner's patients. ${ }^{220}$

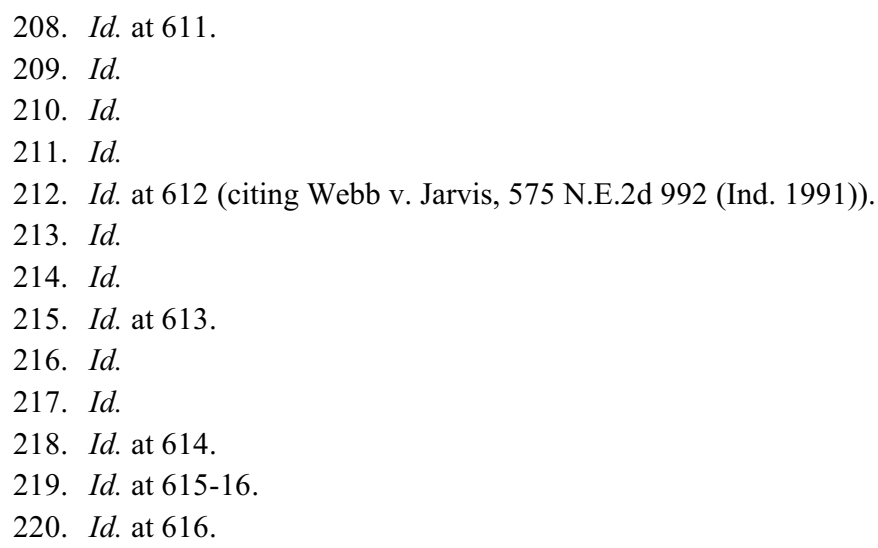




\section{Joint Employers}

In Hall v. Dallman Contractors, $L L C,{ }^{221}$ the court of appeals held that where an employer was a third-tier subsidiary of the same parent corporation under which another entity was also a subsidiary, the employer and entity were joint employers for purposes of the exclusive remedy provision of the Worker's Compensation Act (the Act). ${ }^{222}$

Appellant was injured when, on her way into work, she "tripped and fell over the snow-covered legs of a construction sign." ${ }^{223}$ Appellant then received worker's compensation benefits. ${ }^{224}$ Appellant subsequently filed a negligence action against several other entities. ${ }^{25}$ The entity responsible for physical building maintenance (Entity), including snow and ice removal, filed a motion for summary judgment, contending that Appellant's "claim against it was barred under the exclusive remedy provision of the Act." 226 The trial court granted Entity's motion. ${ }^{227}$ The court of appeals reversed, concluding there was a genuine issue of material fact as to whether Entity was a joint employer of Appellant. ${ }^{228}$

Thereafter, Entity filed a second motion for summary judgment, and, in support thereof, designated evidence that it claimed established Entity and Appellant's employer were subsidiaries of the same parent company; therefore, they were joint employers of Appellant. ${ }^{229}$ The trial court agreed and granted summary judgment in favor of Entity because Appellant's sole and exclusive remedy against a joint employer was the worker's compensation for which she had already received benefits. ${ }^{230}$

On appeal, the court considered the definition of "employer" under the Act as amended in 2000 and 2001 so as to provide "[a] parent corporation and its subsidiaries shall each be considered joint employers of the corporation's, the parent's, or the subsidiaries' employees for purposes of IC 22-3-2-6 [exclusive remedies] and IC 22-3-3-31 [joint service]." ${ }^{, 31}$ Prior to the foregoing amendments, the definition of employer did not include a parent or subsidiary but, rather, permitted an injured employee to pursue a legal claim against any "other person than the employer." 232 The court found the amendments to the definition of employer overruled prior cases holding the injured employee could seek recovery from the parent corporation of the injured employee's employer,

221. 51 N.E.3d 261, 267 (Ind. Ct. App. 2016).

222. Id.

223. Id. at 263 .

224. Id.

225. Id.

226. Id.

227. Id.

228. Id.

229. Id.

230. Id.

231. Id. at 264-65.

232. Id. at 264. 
even where compensation was had under the Act from the employer. ${ }^{233}$

In considering the corporate structure, the court identified Appellant's employer as a third-tier subsidiary of the same parent corporation under which Entity was also a subsidiary. ${ }^{234}$ Because Entity was a subsidiary of the same parent corporation, Entity was a joint employer pursuant to the Act's definition of employer. ${ }^{235}$ Therefore, the court concluded Appellant's action against Entity was barred by the exclusive remedy provision of the Act. ${ }^{236}$

\section{NEGLIGENCE}

\section{A. Bystander Rule}

In Clifton v. McCammack, ${ }^{237}$ the Indiana Supreme Court reviewed the bystander rule and perceived no need to discard or expand upon precedent; therefore, the bystander rule continues to provide recovery for negligent infliction of emotional distress (NEID) if a claimant can establish sufficient "direct involvement," which requires that the claimant "demonstrate that the scene viewed was essentially as it was at the time of the incident, that the victim was in essentially the same condition as immediately following the incident, and that the claimant was not informed of the incident before coming upon the scene." ${ }^{238}$

Clifton and his son Darryl lived in the same residence and were very close. ${ }^{239}$ One morning, Darryl left their home on his moped and was struck shortly thereafter by McCammack's vehicle. ${ }^{240}$ Witnesses moved Darryl's body to the pavement, where resuscitation efforts were unsuccessful, and he died from his injuries. ${ }^{241}$ Approximately thirty minutes after the accident occurred, Clifton was watching television when he saw a news report of a fatal accident involving a moped. ${ }^{242}$ Although the news segment did not provide any pictures or video, Clifton had a "very bad feeling" Darryl was involved. ${ }^{243}$ Clifton drove to the scene of the accident where, from a distance of twenty to twenty-five feet, he could see "Darryl's moped near the front wheel of McCammack's car and a body on the ground covered with a white sheet. ${ }^{244}$ Clifton could not see any blood or signs of injury, but recognized the shoes sticking out from under the sheet as

233. Id. at 265 .

234. Id. at 267 .

235. Id.

236. Id.

237. 43 N.E.3d 213 (Ind. 2015).

238. Id. at $214-15$.

239. Id. at 215 .

240. Id.

241. Id.

242. Id.

243. Id.

244. Id 
Darryl's. ${ }^{245}$ Clifton approached a police officer, who took Clifton to a nearby restaurant before confirming that the victim was in fact Darryl; Clifton did not witness the removal of Darryl's body. ${ }^{246}$

Clifton sued McCammack for negligent infliction of emotional distress. ${ }^{247}$ The parties filed competing motions for summary judgment, and the trial court granted McCammack's. ${ }^{248}$ Clifton appealed. ${ }^{249}$ The court of appeals reversed the trial court, directed entry of summary judgment in favor of Clifton, and remanded for a trial on damages. ${ }^{250}$

On transfer, the supreme court took this opportunity to consider whether Indiana should part from precedent with regard to permitting recovery for NIED. ${ }^{251}$ The court reviewed the history of the bystander rule in Indiana, and examined approaches taken in several jurisdictions. ${ }^{252}$ The court ultimately concluded the requirements crafted to pursue a successful bystander claim in Indiana, along with the fact that those requirements are to be determined as a matter of law, "appropriately address the various public policy concerns this particular tort implicates." ${ }^{.253}$ In other words, the court concluded that Indiana's rule "strikes the appropriate balance between allowing authentic claims to proceed while also curbing the real issues of open-ended liability, fraudulent claims, and the ubiquity of this type of injury." ${ }^{254}$

In a fairly straightforward analysis, the court determined Clifton was not entitled to recover under this theory. ${ }^{255}$ In so holding, the court noted that before Clifton arrived on the scene, both the scene and Darryl's body had materially changed from the way they appeared immediately after the accident; "Clifton did not experience the 'uninterrupted flow of events' following the collision" (i.e., before there were significant changes to the scene and Darryl's body), and Clifton learned indirectly of the incident before arriving at the scene. ${ }^{256}$ The court's analysis led it to conclude Clifton did not satisfy the elements of the bystander rule, and therefore was not entitled to recovery of emotional distress damages. ${ }^{257}$

245. $I d$.

246. Id.

247. Id.

248. Id. at $215-16$.

249. Id. at 216 .

250. Id.

251. Id.

252. Id. at 216-19.

253. Id. at 220.

254. $I d$.

255. Id. at 220-23.

256. Id. at 222 .

257. Id. at 223. 


\section{B. Premises Liability}

In Schneider v. Paragon Realty, $L L C,{ }^{258}$ the court of appeals held a property management company that contracts with a landowner to perform certain administrative services and to maintain the physical integrity of the common areas used by invitees does not have or assume a duty to protect patrons leaving a bar from dangers associated with getting in a car with an intoxicated driver. ${ }^{259}$

Between 6:00 PM and 10:00 PM, Plaintiff consumed five vodka drinks at home before going with a friend to a local bar. ${ }^{260}$ Over the course of four hours at the bar, Plaintiff consumed three beers and three shots of whiskey, and her friend also consumed alcoholic beverages. ${ }^{261}$ Plaintiff left the bar in her friend's vehicle, and her friend was driving. ${ }^{262}$ Plaintiff's friend "lost control of the car and crashed into a ditch." ${ }^{263}$ Plaintiff sustained serious injuries as a result of the crash, and was rendered paraplegic. ${ }^{264}$

Plaintiff filed a complaint against, among others, Paragon, the property manager hired by the property owner. ${ }^{265}$ The trial court granted Paragon's motion for summary judgment. ${ }^{266}$ The court noted this was "an unusual premises liability case in that Paragon [was] not a landowner," but rather a property management company hired by the landowner. ${ }^{267}$ The question was thus whether Paragon was in control of the premises when the accident occurred. ${ }^{268}$ The court looked to the property management agreement, which defined Paragon's role as a limited agent of the property owner whose duty was to maintain "the physical integrity of the common areas used by invitees." ${ }^{269}$ This duty did not include a "duty to "police' the parking lot or any obligation to invitees beyond the physical maintenance of the property. ${ }^{270}$ The court therefore held Paragon was entitled to summary judgment. ${ }^{271}$

\section{Comparative Fault Act}

In Shelton v. Kroger Ltd. Partnership $I,{ }^{272}$ the court of appeals held a

258. 55 N.E.3d 374 (Ind. Ct. App. 2016), reh'g denied; No. 32A01-1511-CT-1858, 2016 Ind. App. LEXIS 275 (Ind. Ct. App. July 25, 2016), trans. denied, 62 N.E.3d 1202 (Ind. 2016).

259. Id. at 380 .

260. Id. at 375 .

261. Id.

262. $I d$.

263. Id.

264. $I d$.

265. Id. at 376 n.2.

266. Id. at 377 .

267. Id. at 378 .

268. Id. at 379 .

269. Id.

270. Id. at 379-80.

271. $I d$. at 380 .

272. 58 N.E.3d 229 (Ind. Ct. App.), trans. denied, 64 N.E.3d 1205 (Ind. 2016). 
pharmacy that is not a qualified healthcare provider is not exempted from the application of the Comparative Fault Act. ${ }^{273}$

Decedent's estate filed a proposed complaint with the Indiana Department of Insurance (IDI), alleging decedent's death was a result of medical complications that arose after taking a prescribed medication. ${ }^{274}$ The estate named several defendants, including the Kroger pharmacy that dispensed the prescription medication. ${ }^{275}$ After receiving notice that the pharmacy was not a qualified health provider subject to the Medical Malpractice Act (MMA), the decedent's estate filed a wrongful death action in the trial court. ${ }^{276}$ After other named defendants settled with the decedent's estate, the pharmacy was granted leave to amend its answer to assert a non-party defense against the named defendants who settled their claims and were dismissed from the action. ${ }^{277}$ The trial court subsequently granted the pharmacy's partial summary judgment motion, concluding the pharmacy was entitled to a credit or set-off for the settlements reached by the other named defendants. ${ }^{278}$

The court noted that " $[u]$ nder Indiana's comparative fault scheme, a named defendant may assert a 'nonparty' defense, seeking to attribute fault to a nonparty rather than to the defendant." 279 The Comparative Fault Act expressly exempts actions brought against a qualified health care provider ${ }^{280}$ The court held because the IDI determined the pharmacy was not a qualified health care provider under the MMA, the pharmacy was likewise not a health care provider exempted from the Comparative Fault Act. ${ }^{281}$ The pharmacy was thereby not entitled to a credit or set-off with regard to settlements reached with other named defendants. ${ }^{282}$ The pharmacy's only option to limit its liability was through its asserted non-party defense. ${ }^{283}$ The trial court's summary judgment ruling was therefore reversed. ${ }^{284}$

\section{Duty of Drivers to Avoid Injuries to Other Motorists}

In J.B. Hunt Transport, Inc. v. Guardianship of Zak, ${ }^{285}$ the court of appeals held the extent of a driver's duty to use ordinary care to avoid injuries to other motorists and to whom such duty is owed are issues "heavily laden with factual

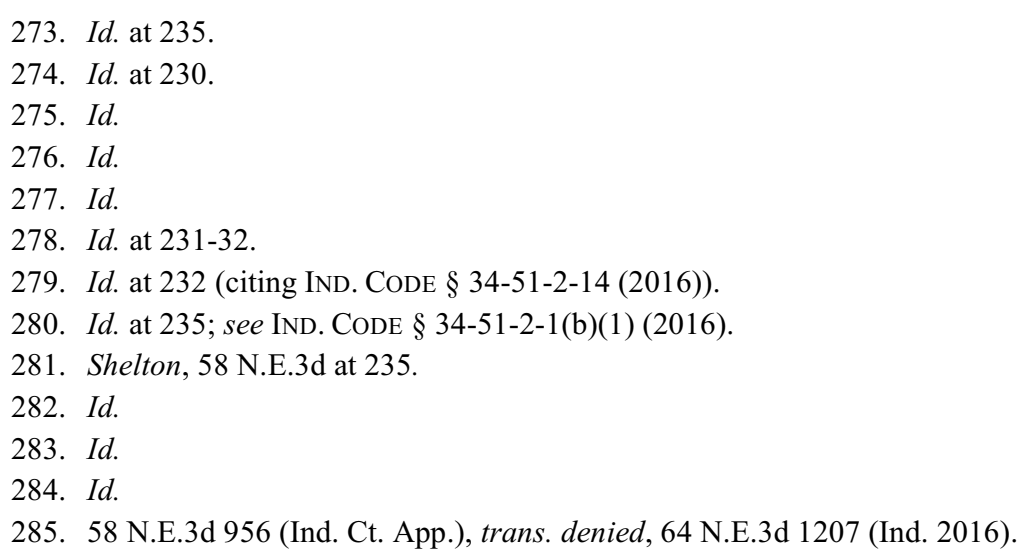


questions that must be answered by a jury." 286

While traveling in snowy conditions and driving at seventy miles per hour in the left lane of an interstate, the driver lost control of the semi he was driving for J.B. Hunt, and he ended up jackknifed and disabled in the median. ${ }^{287}$ The driver did not activate his flashers or use any other visible warning sign, such as triangle reflectors, to indicate the location of the semi in the median, nor did J.B. Hunt instruct him to do so. ${ }^{288}$ An hour later, a vehicle in which Zak was a passenger slid off the same part of the interstate and struck the semi in the median. ${ }^{289}$ As a result of the accident, Zak sustained permanent, serious brain damage. ${ }^{290}$ Following the accident, J.B. Hunt reviewed the accident and issued a report indicating its conclusion that the first accident was preventable; and therefore, terminated the driver's employment. ${ }^{291}$

Zak's guardians (Appellee) filed a negligence action against the driver and J.B. Hunt (Appellants); the jury returned a verdict in favor of Appellee. ${ }^{292}$ During a third trial, the issues of liability and damages were tried together. ${ }^{293}$ Appellants argued they were unjustly prejudiced because the tragic and sympathetic nature of Zak's injuries played on the jury's sympathies as it considered the issue of liability. ${ }^{294}$ The trial court found Appellants did not offer persuasive argument on the issue of liability and expressed its "confidence in the ability of a jury to ably decide the separate question of liability in accordance with the court's instructions. ${ }^{295}$ The court of appeals approved the trial court's reasoning. ${ }^{296}$

The court of appeals also determined the trial court properly denied Appellants' motion for summary judgment and motion for directed verdict based on Appellants' claim that Appellee failed to establish duty and proximate cause as a matter of law. ${ }^{297} \mathrm{~W}$ ith regard to the issue of duty, Appellants argued Zak was not a motorist to whom a duty was owed because the vehicle she was in was an hour away at the time of the semi's initial accident. ${ }^{298}$ Appellants also argued they owed no duty to Zak because J.B. Hunt's driver and Zak were not using a common highway simultaneously. ${ }^{299}$ The court refused to create a bright-line rule to whom a driver owes a general duty of reasonable care and left the factual

\footnotetext{
286. Id. at 971-72.

287. Id. at 961 .

288. Id.

289. Id. at 962 .

290. Id.

291. Id.

292. Id. at 963.

293. $I d$.

294. Id.

295. Id. at 964 .

296. Id.

297. Id. at 972 .

298. Id. at 971.

299. Id.
} 
questions and issues regarding probable cause for the jury to decide. ${ }^{300}$

The court of appeals also rejected Appellants' challenge to the sufficiency of the evidence, concluding from the evidence presented, a reasonable jury could have determined Appellants breached their duty of care owed to Zak, and their negligent actions proximately caused her injuries. ${ }^{301}$

\section{INSURANCE}

\section{A. Negligent Procurement}

In Schmidt v. Indiana Insurance Co. ${ }^{302}$ the Indiana Supreme Court held to defeat a negligent procurement claim, evidence must exclude the possibility that other types of insurance coverage for the property could have been obtained and issued. ${ }^{303}$

Schmidt contacted an insurance agency (Agents) to obtain insurance on property that was "vacant, uninhabitable, undergoing renovation, and intended for rent." ${ }^{304}$ Agents submitted an application for fire insurance on the dwelling, but did not disclose the vacancy, condemnation, renovation, or rental status of the property ${ }^{305}$ The insurance company issued a policy on the property based upon the application. ${ }^{306}$ After a fire destroyed the property, "[T]he insurance company denied coverage and exercised its right to rescind the policy" on the basis that it "contained material misrepresentations and false statements about the property." ${ }^{307}$ Schmidt filed a complaint against Agents and the insurance company. ${ }^{308}$ The trial court granted summary judgment in favor of all defendants; Schmidt appealed. ${ }^{309}$ The supreme court granted transfer to review Agents' summary judgment motion, but affirmed the court of appeals' grant of summary judgment in the insurance company's favor. ${ }^{310}$

Schmidt claimed Agents were negligent in relating the contents of the application for the dwelling fire policy. ${ }^{311}$ The court noted that even though Schmidt did not specifically state a claim for negligent procurement in his complaint, he raised such a claim in response to Agents' motion for summary judgment, and Agents did not challenge the propriety thereof. ${ }^{312}$ Schmidt again

300. Id. at 972 .

301. Id. at 973 .

302. 45 N.E.3d 781 (Ind. 2015).

303. Id. at 788 .

304. Id. at $783-84$.

305. Id. at 784 .

306. Id.

307. Id.

308. Id.

309. Id.

310. Id.

311. Id. at 786-87.

312. Id. at 786 . 
raised the negligent-procurement claim in his appellant's brief and Agents impliedly consented to litigation of the issue by responding thereto. ${ }^{313}$ The court thus determined Schmidt had sufficiently asserted a theory of liability based on negligent procurement of insurance. ${ }^{314}$

Regarding Schmidt's first claim, the supreme court held summary judgment was appropriate because Schmidt failed to rebut Agents' evidence showing that Schmidt "suffered no damage because, even if the insurance application had fully disclosed the accurate condition and usage of the property, no dwelling fire policy would have been issued." ${ }^{315}$ Because Schmidt did not designate evidence to the contrary, there was no genuine issue of fact regarding proximate causation. ${ }^{316}$

The court then considered Schmidt's negligent-procurement claim. ${ }^{317}$ "To succeed at trial on [a] claim [of] negligent procurement, the plaintiff [must] demonstrate (1) a duty defendants owed him, (2) a breach of that duty by the defendants, and (3) an injury to him proximately caused by the breach.",318 Regarding this claim, the supreme court held summary judgment was inappropriate because the agent "failed to exclude the possibility that other types of fire insurance coverage for the property could have been obtained and issued." ${ }^{319}$

\section{B. Conflicting Limitation and Requirement to Get Limits}

In State Farm Mutual Automobile Insurance Co. v. Jakubowicz, ${ }^{320}$ the Indiana Supreme Court held that where an automobile insurance policy's three-year limitation period was in direct conflict with a requirement to exhaust liability coverage limits, the policy was ambiguous and should be construed in the insured's favor. ${ }^{321}$

The insureds were involved in an automobile accident and suffered substantial injuries. ${ }^{322}$ They filed suit against the other driver "seeking damages for medical and property damage payments." ${ }^{323}$ Nearly two and one-half years after the accident, they put their own insurer on notice that they would likely pursue an underinsured motorist (UIM) claim. ${ }^{324}$ More than three years after the accident, the insureds sought leave to amend their complaint to add a UIM claim

\footnotetext{
313. Id.

314. $I d$.

315. Id. at 787 .

316. Id. at $787-88$.

317. Id. at 788 .

318. Id. at 785 .

319. Id. at 788 .

320. 56 N.E.3d 617 (Ind. 2016).

321. Id. at 618 .

322. Id.

323. $I d$.

324. Id.
} 
against their insurer. ${ }^{325}$ The trial court denied the insurer's motion for summary judgment, but the court of appeals reversed, directing entry of summary judgment in favor of the insurer. ${ }^{326}$

The insured's automobile insurance policy specified that a UIM claim must be brought within three years of the accident and also required that the insured must fully comply with all provisions of the policy prior to bringing such suit, including exhaustion of the tortfeasor's policy limits. ${ }^{327}$ However, in this case, the insured could not both exhaust the torfeasor's policy limits and file a UIM suit within the three-year limitation period. ${ }^{328}$ On transfer, the supreme court determined the insurer's policy provisions were in "direct conflict" and the policy made no exceptions or carve-outs that permitted an insured to file suit before exhausting policy limits. ${ }^{329}$ The policy was therefore deemed ambiguous and, as such, was construed in favor of the insured. ${ }^{330}$ The supreme court held the insurer was not entitled to summary judgment. ${ }^{331}$

\section{Malpractice and Disclosure}

In Bar Plan Mutual Insurance Co. v. Likes Law Office, $L L C,{ }^{332}$ the court of appeals held coverage for an attorney's alleged malpractice was precluded by the exclusionary provision given the attorney's failure to disclose probable legal malpractice action in his renewal application. ${ }^{333}$

Attorney Likes represented a personal injury client against Becker. ${ }^{334}$ During the pendency of the proceedings, Likes delayed responding to discovery requests. ${ }^{335}$ Likes finally submitted responses to the discovery requests one day before a court-ordered deadline. ${ }^{336}$ Opposing counsel filed a motion for sanctions claiming that dismissal of the cause was in order because Likes had provided false and misleading answers to interrogatories and deliberately concealed evidence. ${ }^{337}$ Likes did not respond to the motion. ${ }^{338}$ After a hearing, the court granted the motion and dismissed the action on March 16, 2010. ${ }^{339}$ On March 29,

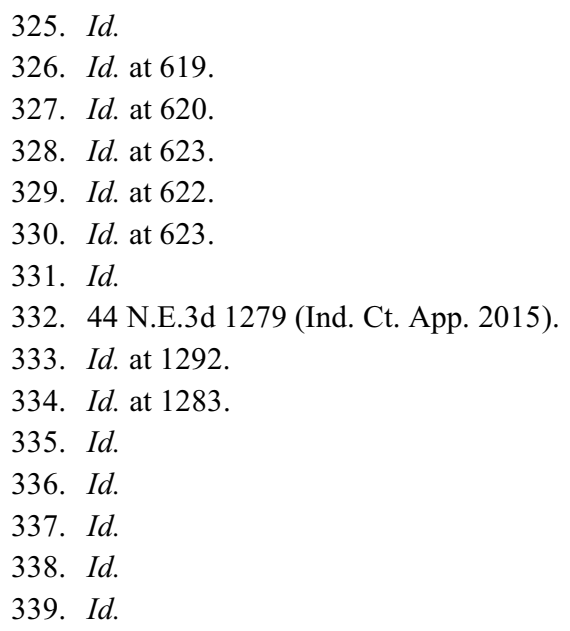


2011, the court of appeals reversed the trial court's decision. ${ }^{340}$ The losing party pursued transfer to the Indiana Supreme Court on April 28, 2011. ${ }^{341}$ Likes responded to the transfer petition on May 17, 2011. ${ }^{342}$ On January 18, 2012, the supreme court reversed the court of appeals and affirmed the trial court's decision to dismiss the action. ${ }^{343}$

Likes was insured under several professional liability insurance policies issued by the bar plan (Bar Plan). ${ }^{344}$ Likes submitted a renewal application on November 14, 2011. ${ }^{345}$ The policy was effective from December 1, 2011 through December 1, 2012. ${ }^{346}$ Likes did not identify any possible claims against him in his renewal application. ${ }^{347}$ On November 2, 2012, Likes' personal injury client filed a complaint against Likes for legal malpractice based on the dismissal of the client's negligence claim. ${ }^{348}$ Likes notified Bar Plan of the action, but Bar Plan denied coverage and indemnification on the ground that Likes failed to notify it of his potential liability as soon as there was a reasonable basis to believe he had committed acts or omissions that could give rise to a malpractice claim, as required under the policy. ${ }^{349}$

The court of appeals concluded "Likes was put on notice that Becker was [seeking] an affirmance of the trial court's dismissal of [the] cause" when the petition for transfer to the supreme court was filed on April 28, 2011. ${ }^{350}$ Accordingly, when Likes signed his renewal application on November 14, 2011, he "knew or reasonably should have known" of a probable malpractice claim. ${ }^{351}$

\section{Miscellaneous}

\section{A. Defamation}

In Wartell v. Lee, ${ }^{352}$ the court of appeals held although arguably defamatory, statements that are generalizations about character, not objectively verifiable, and do not impute misconduct are not defamatory per se. ${ }^{353}$

Lee, a local businessman, wrote a private letter expressing his concerns about

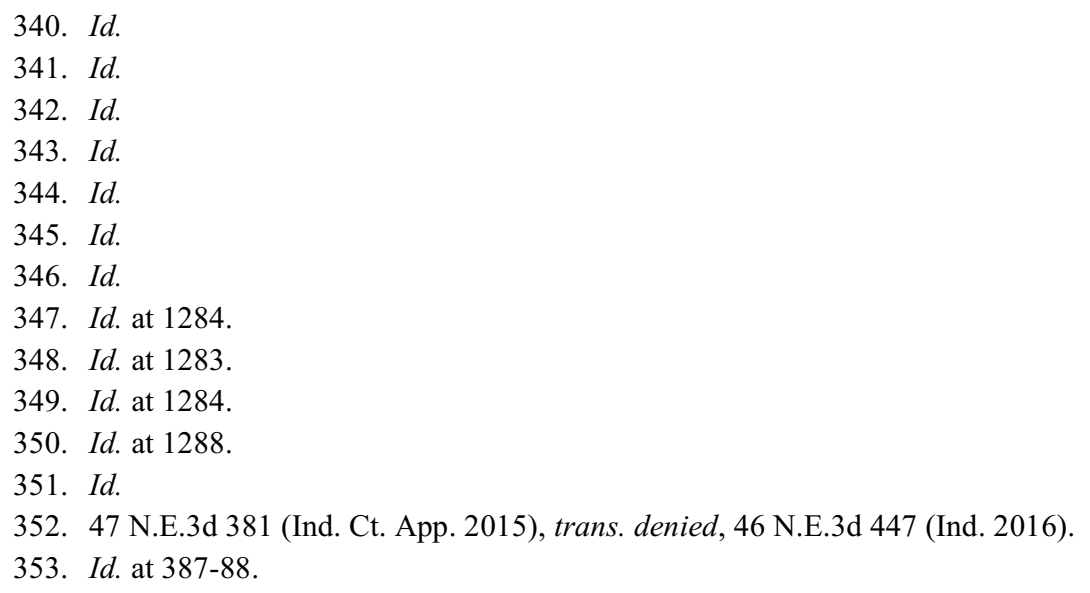


the request to extend Wartell's term as Chancellor for IPFW. ${ }^{354}$ Lee's letter included the following statements, which Wartell claims establish defamation per se:

"[Wartell's] word not always serving as his bond."

"Too often, with persons in a variety of capacities in a variety of situations, he has broken faith."

"Lack of integrity."

"How can IPFW be the leading force it should be in our community and among our small area universities when too frequently its chancellor's character is at issue."

"In the past couple of year [sic] it has become clear that significant financial support from foundations and area business will be hard to come by while [Wartell] remains as chancellor."

" $[\mathrm{W}] \mathrm{e}$ deserve a chancellor with impeccable integrity, the willingness to cooperate with other area universities, and the esteem to inspire complete trust from our business community." 355

In the court's discussion, it described:

"For a statement to be actionable [as defamation per se], it must be clear that it contains objectively verifiable fact regarding the plaintiff. If the speaker is merely expressing his subjective view, interpretation, or theory, then the statement is not actionable." Meyer v. Beta Tau House Corp., 31 N.E.3d 501, 515 (Ind. Ct. App. 2015) (emphasis added) (citing Hamilton v. Prewett, 860 N.E.2d 1234, 1243 (Ind. Ct. App. 2007). "In an action for defamation per se, the words used must have defamatory imputation on their face. The circumstances in which the statements were made have no bearing on whether the statements constitute defamation per se." Big Wheel Restaurants, Inc. v. Bronstein, 158 Ind. App. 422, 302 N.E.2d 876, 879 (Ind. Ct. App. 1973) (emphasis added). ${ }^{356}$

The court determined that Lee's statements were "vague and not objectively verifiable without referring to extrinsic evidence." ${ }^{357}$ Moreover, the words used were not defamatory on their face. ${ }^{358}$ Although Lee's statements were arguably defamatory, the court held "the vagueness with which they are stated prevents them from imputing misconduct and rising to the level of defamation per se."359

In Ali v. Alliance Home Health Care, $L L C,{ }^{360}$ the court of appeals held: (1) a defamation claim fails if specificity is lacking; ${ }^{361}$ (2) statements to law

354. Id. at 383 .

355. $I d$. at 384 .

356. Id. at 385 .

357. Id. at 387 .

358. Id.

359. Id.

360. 53 N.E.3d 420 (Ind. Ct. App. 2016).

361. Id. at 428 . 
enforcement concerning thefts are subject to the qualified privilege exception to defamation; ${ }^{362}$ (3) statements to an insurance company fall under the commoninterest qualified privilege exception; ${ }^{363}$ (4) communications with the Indiana State Department of Health and Department of Workforce Development are expressly protected by statute ${ }^{364}$ and (5) an investigator's statements that are not false are not defamatory. ${ }^{365}$

Appellant was employed by Alliance as a certified nurse's aide (CNA) and a certified home health aide (CHHA). ${ }^{366}$ One of Alliance's patients and his wife discovered several pieces of jewelry were missing from their home; one of the pieces of missing jewelry was subsequently found in the possession of another patient, who claimed the item of jewelry had replaced a piece of his jewelry that had itself disappeared. ${ }^{367}$ An investigation revealed Appellant was the only Alliance employee who had worked for both patients during the timeframe pinpointed for the thefts, and Appellant's employment was therefore terminated. ${ }^{368}$ When Alliance was asked to provide a reason for Appellant's termination for purposes of unemployment benefits, Alliance responded that the reason was theft. ${ }^{369}$ Alliance also contacted the Indiana State Department of Health (ISDH) regarding its theft investigation. ${ }^{370}$ Following an evidentiary hearing, ISDH concluded Appellant had misappropriated the jewelry from Alliance's patients and, as a result, revoked her healthcare certifications. ${ }^{371}$

Appellant "filed a civil action against [Alliance and others (Appellees)], alleging defamation, malicious prosecution, false imprisonment... vicarious liability, intentional infliction of emotional distress, and negligent infliction of emotional distress." ${ }^{372}$ The trial court granted summary judgment in favor of all Appellees. ${ }^{373}$

With regard to her defamation claim, the court of appeals noted Appellant failed to sufficiently identify which statements were allegedly defamatory; and, although Appellant made several attempts to supplement her argument with specific examples, her claim was still deficient. ${ }^{374}$ The court concluded Appellees' statements to law enforcement concerning Appellant's connection to the thefts were subject to the qualified privilege exception, which provides that "communications made to law enforcement to report criminal activity are

362. Id. at 429 .

363. Id.

364. Id. at 430 .

365. Id. at 431 .

366. Id. at $425-26$.

367. Id. at 426 .

368. Id.

369. Id.

370. Id.

371. Id.

372. Id. at 427.

373. Id.

374. Id. at 428 . 
qualifiedly privileged." ${ }^{375}$

The court concluded Appellees' correspondence with its insurance agent were protected by the common-interest qualified privilege because "communication between Alliance and its insurer was a good faith attempt to discern whether the insurer would cover its client's loss, an issue of common interest to both insurer and insured. ${ }^{376}$ The court also concluded the communications with ISDH and the Department of Workforce Development were expressly protected by statute, and Appellant did not establish that Appellees had ill will or lacked belief in the truth of the findings contained in their report to ISDH. ${ }^{377} \mathrm{~W}$ ith regard to statements made by a private investigator hired by Alliance to look into the thefts, the court found such statements were not defamatory because they were not false, and he was "simply reporting" the evidence that led him to his conclusion that Appellant was the perpetrator. ${ }^{378}$

The court concluded Appellant's malicious prosecution claim failed because it was the "prosecutor, not Appellees, [who] initiated the [criminal] action" based upon the police investigation that gave rise to a determination of probable cause. ${ }^{379}$ Appellant's false-imprisonment claim is premised upon her assertion that she never would have been arrested if Appellees had not provided false information; the court concluded the prosecutor acted on evidence gathered by law enforcement in determining that "probable cause existed to charge [Appellant] with theft," and Appellant failed to present evidence indicating a malicious or fraudulent motive to rebut the finding of probable cause. ${ }^{380}$

The court concluded summary judgment was proper on Appellant's claim of intentional infliction of emotional distress, finding as a matter of law that the manner in which the investigation was handled was reasonable, and the conduct of those involved was not outrageous. ${ }^{381}$ Finally, the court held Alliance could not be vicariously liable for the private investigator's conduct because the investigator was not an employee of Alliance. ${ }^{382}$

\section{B. Wrongful Death}

In Hoker Trucking, LLC v. Robbins, ${ }^{383}$ the court of appeals held under Indiana's General Wrongful Death Statute (GWDS), ${ }^{384}$ if a decedent is survived by a spouse or dependent(s), attorneys' fees do not qualify as compensatory

375. Id. at 429 .

376. Id. at 430 .

377. Id. at $430-31$.

378. Id. at 431 .

379. Id. at 432 .

380. Id. at $432-33$.

381. Id. at 434 .

382. Id.

383. 43 N.E.3d 677 (Ind. Ct. App.), modified on reh'g, 49 N.E.3d 191 (Ind. Ct. App. 2015), trans. denied, 50 N.E.3d 146 (Ind. 2016).

384. See IND. CodE § 34-23-1-1 (2016). 
damages and are thus not recoverable; the estate ultimately bears the burden for payment thereof. ${ }^{385}$

Robbins's husband was involved in a motor vehicle accident with a tractortrailer operated by an employee of Hoker Trucking. ${ }^{386}$ Robbins's husband died from the injuries suffered in the accident. ${ }^{387}$ Just short of two years after the accident, Robbins, as her husband's surviving spouse, filed a wrongful death action against Hoker Trucking. ${ }^{388}$ The matter proceeded to trial and concluded with a jury verdict in favor of Robbins. ${ }^{389}$ Thereafter, Robbins filed a request for compensable damages comprising attorneys' fees and prejudgment interest under the GWDS. ${ }^{390}$ The trial court awarded Robbins attorneys' fees of $\$ 2,400,000$ and prejudgment interest on the jury verdict in the amount of $\$ 622,028.11 .{ }^{391}$ Hoker Trucking appealed. ${ }^{392}$

The court of appeals cited the Indiana Supreme Court's decision in SCI Propane, LLC v. Frederick ${ }^{393}$ in which the Indiana Supreme Court construed the language of the GWDS narrowly and concluded in cases where the "decedent is survived by a spouse and/or dependents," attorneys' fees do not qualify as damages under the GWDS. ${ }^{394}$ The court of appeals reasoned that in such cases, attorneys' fees do not "evolve from a deprivation to a survivor." $" 395$ This is in contrast to a second defined category under the GWDS, i.e., decedents who are not survived by a widow or dependents, wherein the "estate is expressly entitled to recover reasonable attorneys' fees in 'prosecuting or compromising the action. " ${ }^{396}$ The court reversed the trial court's order granting Robbins attorneys' fees and prejudgment interest. ${ }^{397}$

On rehearing, the court clarified that the trial court ordered prejudgment interest on the jury verdict only and not on the award of attorneys' fees. ${ }^{398}$ The court therefore looked to the prejudgment interest statutes ${ }^{399}$ and concluded the trial court was permitted, but not required, to grant prejudgment interest on the verdict. ${ }^{400}$ After considering the circumstances, the court held the trial court did

385. Hoker Trucking, 43 N.E.3d at 679.

386. Id. at 678 .

387. Id.

388. Id.

389. Id.

390. Id.

391. Id.

392. Id.

393. 39 N.E.3d 675 (Ind. 2015).

394. Hoker Trucking, 43 N.E.3d at 678 (citing SCI Propane, 39 N.E.3d at 681).

395. Id. at 679 (quoting SCI Propane, 39 N.E.3d at 680).

396. Id. at 679 (quoting IND. CODE $§ 34-23-1-1$ (2016)).

397. Id. at 680 .

398. Hoker Trucking, LLC v. Robbins, 49 N.E.3d 191, 192 (Ind. Ct. App. 2015), trans. denied, 50 N.E.3d 146 (Ind. 2016).

399. See Ind. CODE $\S \S 34-51-4$ to -7 (2016).

400. Hoker Trucking, 49 N.E.3d at 192. 
not abuse its discretion in awarding prejudgment interest on the jury's verdict and therefore modified its previous decision accordingly. ${ }^{401}$

In Lomax v. Michael, ${ }^{402}$ the court of appeals held genuine issues of material fact existed regarding whether Appellant was a dependent next of kin as required to recover pecuniary damages related to his uncle's death. ${ }^{403}$

Decedent was Appellant's uncle and last living relative on his father's side of the family. ${ }^{404}$ Decedent had lived with Appellant on and off since Appellant was a child and began living with Appellant on a full-time basis approximately five years before his death. ${ }^{405}$ During this time, Decedent contributed financially to the household and helped maintain the home. ${ }^{406}$ Appellant described his relationship with decedent as that of a father and son. ${ }^{407}$ Decedent died from injuries sustained when the bicycle he was riding was struck by a motorist. ${ }^{408}$ Appellant "filed a wrongful death action in both an individual capacity and on behalf of the Estate." "409 Appellant alleged that he was decedent's "dependent next of kin" for purposes of the GWDS. ${ }^{410}$

The court of appeals noted that a dependent next of kin need not be totally dependent and that the decedent need not have been under a legal obligation to support the next of kin. ${ }^{411}$ In light of the evidence that the decedent "regularly contributed a significant portion of his monthly government benefits" to cover household expenses and that such amount was "significant in terms of the costs associated with maintaining [the] household," the court held questions of fact existed whether Appellant was a dependent next of kin. ${ }^{412}$

\section{Indemnification}

In In re Indiana State Fair Litigation, ${ }^{413}$ the Indiana Supreme Court held indemnification, especially when retroactive, cannot be implied from a course of dealing when it is not expressed by clear and unequivocal contract language. ${ }^{414}$

Over the course of ten years, the parties followed a standard routine whereby Mid-America Sound, the provider of equipment and services for concerts, would

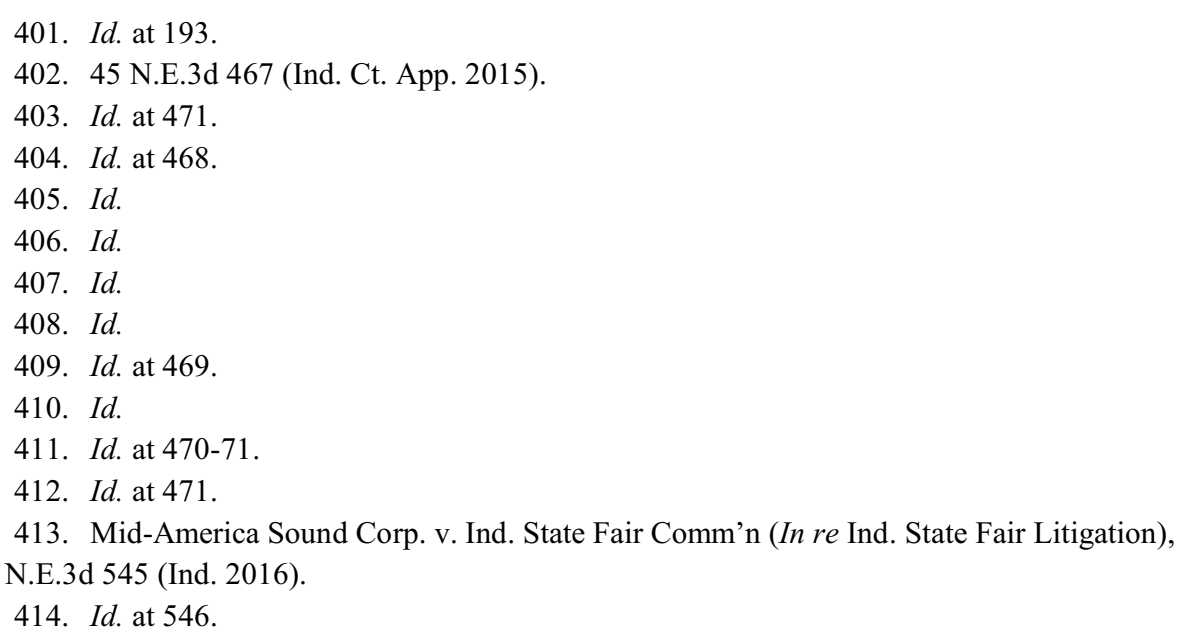


submit a blank voucher form with invoices attached after the conclusion of the fair, and the State Fair Commission would then verify the invoices and sign the voucher to authorize payment. ${ }^{415}$ After tragedy struck during a concert at the grandstand stage in August 2011, the victims and their families filed lawsuits against numerous defendants. ${ }^{416}$ In December 2011, while the lawsuits were still pending, Mid-America sent the Commission a two-sided invoice for the lease of equipment and services along with a single-sided voucher form. ${ }^{417}$ The invoice and voucher form covered, in part, the equipment and services that were being provided at the time of the August 2011 accident. ${ }^{418}$ Mid-America later filed a "third-party lawsuit against the Commission, claiming that two sentences located on the back of the December 2011 invoice entitled it to [retroactive] indemnification for its own negligence in relation to the August 2011 [incident].".419

The supreme court noted that Indiana law requires "clear and unequivocal" language in indemnification provisions and that such language is to be strictly construed. ${ }^{420}$ The court further observed that retroactive indemnification provisions are particularly disfavored. ${ }^{421}$ It was undisputed that the indemnity language contained in the invoice and voucher form did not expressly extend to losses prior to the invoice date. ${ }^{422}$ Nonetheless, Mid-America argued that its course of dealing with the Commission established such an agreement. ${ }^{423}$ The supreme court held because indemnity provisions must be expressed unambiguously-especially when retroactive - they may not be inferred from a course of dealing. ${ }^{424}$

\title{
D. Crime Victim Relief Act
}

In Staggs v. Buxbaum, ${ }^{425}$ the court of appeals held liability under the Crime Victim Relief Act (CVRA) ${ }^{426}$ is examined under a preponderance of the evidence standard. ${ }^{427}$

Staggs completed a Seller's Residential Real Estate Disclosure Form in which she made material fraudulent misrepresentations about the septic system and

\author{
415. Id. at 547 . \\ 416. Id. \\ 417. Id. \\ 418. Id. \\ 419. Id. \\ 420. Id. at $548-49$. \\ 421. Id. at 550 . \\ 422. Id. at 551 . \\ 423. Id. at 552 . \\ 424. Id. at 554 . \\ 425. 60 N.E.3d 238 (Ind. Ct. App.), trans. denied, 62 N.E.3d 1201 (Ind. 2016). \\ 426. IND. CoDE § 34-24-3-0.2 to -4 (2016). \\ 427. Staggs, 60 N.E.3d at 246.
}


moisture in the basement. ${ }^{428}$ Buxbaum purchased the property based in part on Staggs' representations and soon thereafter discovered that there was no septic system and that the basement leaked ${ }^{429}$ Buxbaum expended substantial monies to remedy the problems and then filed a complaint against Staggs for fraudulent misrepresentation. ${ }^{430}$ The trial court found Staggs was liable for fraudulent misrepresentation and also awarded Buxbaum treble damages pursuant to the CVRA. ${ }^{431}$ In a previous appeal involving these same facts, the court of appeals in an unpublished opinion ${ }^{432}$ reversed the trial court's award of treble damages because the trial court did not make a specific finding of criminal culpability required by Wysocki v. Johnson, ${ }^{433}$ which held "[a]n actual criminal conviction is not required for recovery [under the CVRA]" to support an award of treble damages. ${ }^{434}$ "[A] claimant merely must prove each element of the underlying crime by a preponderance of the evidence." ${ }^{435}$

On remand in Staggs, the trial court reconsidered the evidence and concluded, by a preponderance of the evidence, Staggs did act in a heinous and criminally culpable manner when she completed her sales disclosure form and made material misrepresentations. ${ }^{436}$ Pursuant to the CVRA, the trial court entered an award for treble damages in favor of Buxbaum. ${ }^{437}$ Staggs appealed, arguing the damages award should have been made under a clear and convincing standard, not by a preponderance of the evidence. ${ }^{438}$ In the appeal upon remand, the court of appeals found no merit to Staggs's claim, concluding the Indiana Supreme Court's statements in Wysocki made clear that CVRA liability is examined under a preponderance of the evidence standard. ${ }^{439}$

428. Id. at 240 .

429. Id.

430. Id.

431. Id. at 241 .

432. Staggs v. Buxbaum, 29 N.E.3d 820, No. 47A01-1406-PL-254, 2015 Ind. App. LEXIS 194 (Ind. Ct. App. Feb. 25, 2015).

433. 18 N.E.3d 600 (Ind. 2014).

434. Id. at 606.

435. Id.

436. 60 N.E.3d at 244 .

437. Id. at 248 .

438. Id. at 245 .

439. Id. at 245-46. 